\title{
Diagnostics of Formation the Subject Competences in Future Doctors
}

\author{
Khmil Iryna \\ Senior Lecturer \\ Bogomolets National Medical University (Ukraine, Kyiv)
}

\begin{abstract}
The article analyzes the results of diagnostics of future doctors' motivational-value sphere. The peculiarities of studying the significance of motives in forming subject competences of students are revealed. It is stated that the greatest value for students is the external motives, which reflect the material interest of the individual in the results of their professional activity. In the hierarchy of students' motives, respectively, the following rankings are occupied by motives of prestige, motives of manifestation of personality in the profession and professional motives. The motives of their professional activity characterize the students' interest in the profession of doctor. Proved that the motives of the professional activity itself constitute a valuable basis for the content of the profession.

Keywords: future doctors, student, subject competence, motives, value-motivational sphere, diagnostics, methodology, surveys.
\end{abstract}

Постановка проблеми. В сучасних соціально-економічних умовах функціонування системи охорони здоров'я суттєво зростають вимоги до рівня правової підготовки майбутніх лікарів. Правова підготовка майбутніх лікарів $є$ базовою системотвірною ланкою у формуванні їхніх професійних знань та умінь. Разом з тим спостерігаються протиріччя між запровадженням сучасних форм, методів формування предметних компетентностей у процесі вивчення медичного правознавства та недостатнім науково-методичним забезпеченням, моніторингом цього процесу у закладах вищої медичної освіти, низьким рівнем мотивації студентів. Означені протиріччя потребують негайного вирішення.

Метою статті $є$ діагностика у студентів мотивів вступу в університет, мотивів вивчення медичного правознавства.

Аналіз попередніх досліджень і публікацій. Питання формування предметних компетентностей у своїх працях досліджували А. Будас, Л. Овсієнко, Н. Писименна, О. Пишко та ін. Правова компетентність майбутніх фахівців була предметом вивчення А. Анікіної, С. Воєводіної, Т. Волох, С. Гуріна, Я. Кічук, І. Огороднійчук, О. Панова, М. Полякової та ін. Підготовку фахівців медичної галузі висвітлено у дослідженнях 
М. Асмолова, М. Банчук, О. Волосовець, Л. Войтенко, В. Лазоришенець, М. Мруги, Н. Стучинської, Т. Реви, І. Фещенко, Я. Цехмістера, О. Чалого, Б. Шахова та ін.

Водночас аналіз психолого-педагогічної літератури свідчить про недостатню розробку проблеми формування предметних компетентностей майбутніх лікарів, зокрема в контексті вивчення впливу мотивації на означений процес.

Результати дослідження. Предметну правову компетентність розглядаємо як сукупність набутих майбутнім лікарем знань 3 медичного правознавства, умінь екстраполювати їх у практичну діяльність, здатності розв'язувати пізнавальні завдання правового змісту в освітньому процесі та життєвих ситуаціях. Предметну компетентність з медичного правознавства характеризуємо як показник високої якості їх правових знань, умінь, здатності установлювати зв'язки між набутими знаннями та реальними практичними ситуаціями.

Вивчення рівнів сформованості предметних компетентностей майбутніх лікарів передбачало визначення наявності у студентів провідних ціннісних мотивів вступу до університету, мотивів вивчення медичного правознавства.

Для дослідження мотивів вступу до магістратури студентам було запропоновано анкету, розроблену на основі методики Т. Ільїної «Мотивація навчання у ЗВО». Виявлення провідних мотивів вступу студентів до магістратури здійснювали за такими шкалами: 1) отримання знань (прагнення до отримання знань, допитливість); 2) оволодіння професією (прагнення до оволодіння професійними знаннями, правовими уміннями розвитку професійно важливих якостей); 3) отримання диплому (прагнення до отримання диплому за умови формального засвоєння навчальних предметів, іноді пошук неетичних, незаконних засобів для отримання заліків та оцінки на іспитах).

Результати опитування засвідчують, що більшість студентів надали перевагу мотиву «отримання диплому» - 52,8 \%, мотив «отримання знань» зайняв друге місце, його обрали - 33,9\% респондентів. Мотивом «оволодіння професією» керувались у своєму виборі закладу вищої освіти тільки 13,3 \% майбутніх лікарів. Відтак можемо констатувати, що провідним мотивом навчальної діяльності студентів у даній вибірці виявився мотив «отримання диплому», що ще раз підтверджує низьку мотивацію до оволодіння професією та низький рівень сформованості цінностей, пов'язаних із нею.

Слід зазначити, що серед провідних мотивів навчання майбутніх лікарів мотив 
«отримання диплому» займає перше місце. Отриманий результат можна пояснити, на наш погляд, з одного боку - прагненням підтвердити свою дорослість і незалежність, а з іншого - недостатнім розвитком пізнавального інтересу у певної частини студентів. Мотив «отримання знань» у переважної кількості студентів виражений досить посередньо, мотивація до здобуття знань дещо занижена. Серед мотивів оволодіння професією в обох групах переважають зовнішні мотиви, значущим внутрішнім мотивом $€$ лише позитивне ставлення до певних навчальних дисциплін, які вивчаються в університеті. Можна стверджувати, що ціннісні орієнтації значної частини студентів лежать поза межами професії лікаря. Отже, формування перших двох показників предметних компетентностей («отримання знань» та «оволодіння професією») потребують особливої уваги в процесі підготовки майбутніх лікарів.

Так, рушійною силою будь-якої діяльності, зокрема щодо формування предметних компетентностей, вивчення медичного правознавства $є$ мотивація. Ми вважали за необхідне детальніше дослідити ціннісно-мотиваційну сферу майбутніх лікарів, можливості впливу на неї, також нас цікавили питання організації освітнього процесу (вплив знань і вмінь студентів на процес і результат оволодіння предметними компетентностями 3 медичного правознавства). Усе це обумовило необхідність вивчення значущості мотивів формування предметних компетентностей у майбутніх лікарів у зазначених групах. 3 метою вивчення значущості мотивів нами використовувалася методика самооцінки мотивів, запропонована М. Віленським, П. Образцовим, А. Уманом [3].

Кількість мотивів визначалася необхідністю вибору студентами найбільш значущих для них мотивів, відповідних їх суб'єктивній ранговій системі цінностей, цілей. Результати оцінювання значущості мотивів, які спонукають майбутніх лікарів до формування правової предметної компетентності у процесі навчання медичного правознавства засвідчує, що найбільшу цінність для студентів мають зовнішні мотиви, що відображають матеріальну зацікавленість особистості в результатах своєї професійної діяльності: бажання забезпечити високий заробіток завдяки отриманим знанням, отримати високооплачувану роботу. Отже, престижність на ринку праці, яка асоціюється з їі затребуваністю бачать 16,8 \% студентів та як наслідок, матеріальне благополуччя, пов'язане із професією 29,7 \%. Зовнішній мотив займає чільне місце в 
мотивації навчальної діяльності, але не є визначальним (скоріше за все, він пов'язаний 3 віддаленою перспективою заробляти гроші, а навчальна діяльність розглядається як засіб досягнення цієї мети).

Мотиви престижу професії, які тісно пов'язані із прагненням особистості до самоствердження у суспільстві займають друге рангове місце в ієрархії мотивів навчання. Вища освіта багатьма молодими людьми автоматично сприймається як універсальна цінність, абсолютно логічний етап власного соціального становлення. Поряд із цим тут присутня й статусна мотивація. Для успішного проходження конкурсу, формування корпоративної культури, ефективного засвоєння медичного правознавства необхідний досить високий рівень домагань особистості та інших суб'єктивних факторів. Одержання статусу магістра, за результатами наших досліджень, дотепер сприймається як високий рівень саморозвитку в неформальній молодіжній ієрархії, досягнення значимої чергової (після закінчення бакалаврату) соціально-ієрархічної сходинки. 3 огляду на це, можна констатувати, що сучасні магістри $[4 ; 6 ; 7 ; 10 ; 11 ; 11$; $12 ; 16 ; 17 ; 19]$ недостатньою мірою орієнтовані на навчання заради формування власної громадянської позиції, розбудови країни.

Наступне місце в ієрархії мотивів навчання займають мотиви прояву особистості у професії, що супроводжується особливостями формування самосвідомості особистості в умовах взаємодії з професією (переконаність у власній професійній придатності, у достатньому творчому потенціалі, в тому, що обрана професія $\epsilon$ покликанням та ін.). Ці студенти займають активну соціальну й пізнавальну позицію. Навчання, формування предметних компетентностей відбувається у процесі реалізації власного інтелектуального та особистісного потенціалу. Професійна самореалізація майбутніх лікарів включає пошук «себе в професії», формування професійного іміджу, власного образу «Я», окреслення для себе професійних перспектив та шляхів їх досягнення, побудова своєї діяльності на правовій основі. Їх дії спрямовані на розуміння ступеня відповідності індивідуальних особливостей вимогам професії, яку вони обрали; на розвиток власних можливостей в процесі навчання медичного правознавства. Сформованість такої мотивації $є$ соціально значущою та впливає на результат майбутньої професійної діяльності. 
Важливе місце в мотиваційній структурі навчальної діяльності майбутніх лікарів посів мотив розуміння призначення професії. Мотив розуміння призначення професії формується як інтерес до професії та схильність займатися нею. В ідеалі мотиви розуміння призначення професії повинні збігатися з мотивами вибору. Важливо щоб майбутній лікар був готовий до вирішення професійних завдань, виявляв інтерес до професії та ціннісне ставлення до неї. Так, мотиви розуміння призначення професії відображають також бажання відповідати образу професії й орієнтують на розвиток таких важливих для фахівця професійних якостей, як комунікабельність, уважність, гнучкість, толерантність, емпатія, відповідальність, рефлексія щодо власних вчинків і рішень, порядність, дотримання правових та етичних норм у майбутній професійній діяльності, неприпустимість маніпулювання людьми.

До власне професійних мотивів відносимо мотиви, пов'язані з усвідомленням соціальної та особистісної значущості професійної діяльності лікаря, що підкріплюються задоволеністю результатами самої діяльності (стати висококваліфікованим спеціалістом, забезпечити успішність майбутньої професійної діяльності, домогтися високих результатів діяльності у сфері медицини та ін). Мотиви власне професійної діяльності характеризуються наявністю у студентів інтересу до професії лікаря, прагненням до досягнення успіху в реалізації поставлених цілей. Ця група мотивів пов'язана з такими особистісними якостями, як наполегливість у досягненні кінцевого результату діяльності. Вони складають ціннісну основу змісту професії.

Висновки. Отже, можна стверджувати, що не всі студенти досить усвідомлено підходять до вибору професії, більшість із них не пов'язує майбутню професійну діяльність із правовою підготовкою, знаннями й дотриманням правових норм у професійних взаєминах. Необхідна спеціальна робота щодо розвитку мотивації студентів. Подальшого дослідження потребують такі важливі аспекти цієї проблеми: застосування сучасних інформаційних технологій для формування предметних компетентностей майбутніх лікарів, дистанційна освіта у професійному розвитку лікарів.

\section{References}

1. Bakulina O.S. Suchasni problemy motyvatsii personalu silskohospodarskykh pidpryiemstv [Current problems of motivation of staff of agricultural enterprises]. Rol nauky $u$ 
pidvyshchenni tekhnolohichnoho rivnia i efektyvnosti APK Ukrainy: mater. 2-yi vseukr. nauk.prakt. konf. z mizhnar. uchastiu, (16-18 travnia 2012). Ternopil : Krok, 2012. P. 236-238.

2. Bakulina O.S. Motyvatsiia personalu silskohospodarskykh pidpryiemstv: teoretychnyi aspect [Motivation of staff of agricultural enterprises: theoretical aspect]. Visn. nats. un-tu vodnoho hospodarstva ta pryrodokorystuvannia. 2008. Issue 4(44). P. 3-10.

3. Vilenskij M. Ya. Tehnologii professionalno-orientirovannogo obucheniya $v$ vysshej shkole [Technologies of vocational-oriented education in higher education]. Moskva : Pedagogicheskoe obshestvo Rossii, 2002. 275 p.

4. Ovsiienko L. M. Problemy vprovadzhennia kompetentnisnoho pidkhodu v protses pidhotovky maibutnikh pedahohichnykh kadriv [Implications of implementing the competence-based approach into the process of professional training of future teaches]. Ukrainska mova i literatura $\mathrm{v}$ shkoli: scientific-andmethodological journal. Kyiv: Vydavnytstvo TOV «Lazuryt-Polihraf» Publ., 2011. № 6. Pp. 46-48.

5. Petko S. M. Modeli korporatyvnoho upravlinnia v diialnosti korporatsii na svitovykh rynkakh [Models of Corporate Governance in Corporate Activity of Global Markets]. Molodyi vchenyi. 2015. № 2 (17). Part 2. Pp. 225-229.

6. Pet'ko L.V. Vyklyky XXI stolittia dlia osvitnoho prostoru Ukrainy. Naukovi pratsi ChNU: nauk. zhurnal [The challenges of educational space in the $21-^{\text {st }}$ century] / Chornom. Nats. un-t im. Petra Mohyly; red. Kol.: O.P.Meshchaninov (holova) [ta in.]. - Mykolaiv: Vydvo ChNU imeni Petra Mohyly, 2017. T. 303. Issue 291. P. 10-14 (Pedahohika)

7. Pet'ko L V. Realizatsiia kontseptsii pidhotovky mahistriv $v$ Ukraini dlia roboty $v$ inkliuzyvnomu osvitnomu prostori [The conception of the preparation masters' in Ukraine Implementation to work in an inclusive educational environment] // Aktualni problemy navchannia ta vykhovannia liudei $\mathrm{v}$ intehrovanomu osvitnomu seredovyshchi: $\mathrm{Tr}$. KhI Mizhnar. nauk.-prakt. konf., lystopad 2011 r. Ch. I. Kyiv: VMURL «Ukraina». 2011. P.92-94.

8. Ternopilska V. I. Vidpovidalnist osobystosti: humanitarnyi aspect [Personality responsibility: the humanitarian aspect]. Visnyk Zhytomyr. derzh. un-tu im. I. Franka. 2004. No. 14. P. 47-50.

9. Ternopilska V. I. Teoretychni zasady realizatsii tsinnisnoho pidkhodu u vykhovanni osobystosti [Theoretical bases of realization of value approach in education of personality']. Novi tekhnolohii navchannia. 2016. Issue. 88. P. 118-121.

10. Ternopilska V. I. Suchasni tendentsii motyvatsii navchalno-profesiinoi diialnosti studentiv [Modern tendencies of motivation of students' educational and professional activity]. Visnyk Natsionalnoho universytetu oborony Ukrainy, 2012. 5(30). P. 141-144.

11. Ternopol'skaja V. I., Bakulina O. S. Osobennosti formirovanija professional'noj kompetentnosti budushhih specialistov po nalogooblozheniju i tamozhennomu delu [Features of the formation of professional competence of future specialists in taxation and customs]. Mezhdunarodnyj nauchnyj zhurnal «Progress». Tbilisi : «Progress», 2018. No. 1-2. P. 94-97.

12. Ternopilska V. I. Struktura profesiinoi kompetentnosti maibutnoho fakhivtsia [The structure of professional competence of the future specialist]. Naukovyi visnyk Melitopolskoho derzhavnoho pedahohichnoho universytetu, 2012. No. 9. P. 208-213. 
13. Ternopilska V. I., Chyzhova N. V. Mobilnist osobystosti yak predmet naukovoho doslidzhennia [Personality mobility as a subject of scientific research]. Teoretyko-metodychni problemy vykhovannia ditei ta uchnivskoi molodi. 2016. Issue 20. P. 234-243.

14. Ternopilska V. I., Derev'ianko O. V. Vyznachennia kryteriiv sformovanosti profesiinoi kompetentnosti maibutnikh hirnychykh inzheneriv [Determination of criteria for the formation of future mining engineers'professional competence]. Nauk. chasopys NPU imeni M.P. Drahomanova. Ped. nauky, 2012. Issue 31. P. 264-267.

15. Ternopilska V. I., Kolomiiets T. V., Piontkivska I. O. Dovidnyk $z$ vykhovnoi roboty zi studentamy [Handbook of educational work with students]. Ternopil : Vyd-vo «Bohdan», 2014. $184 \mathrm{p}$.

16. Babiy S., Bezkorovaina O., Matviienko O., Petko St., Ternopilska V., Soichuk R., Stanislavchuk N. Entrepreneurship model of professional development of actuaries in Canada // Journal of Entrepreneurship Education (JEI). USA. 2019. Vol: 22 Issue: 3. P. 1-6.

17. Ovsiienko Liudmyla. Innovative approaches to improving professional training of spesialists in higher educational institutions // Current scientific research: Collection of scientific articles. - Publishing house «BREEZE», Montreal, Canada, 2017. P. 215-220.

18. Ovsiienko L. M. Regularities of competently directed learning of text linguistics of studets' philological specialities // Economics, management, law: socio-economical aspects of development: Collection of scientific articles. Volum 2. Psychology. Pedagogy and Education. - Edizioni Magi - Roma, Italy. 2016. P. 245-250.

19. Pet'ko L. The development of student youth aesthetic culture on professional direction // Topical issues of contemporary science: Collection of scientific articles. - C.E.I.M., Valencia, Venezuela, 2017. P. 188-192.

Translation of the Title, Abstract and References to the Author's Language

УДК 378.147-057.875[34:61]616-051:005.336.2

Хміль І. Ю. Діагностика сформованості предметних компетентностей майбутніх лікарів.

Здійснено аналіз результатів діагностики мотиваційно-ціннісної сфери майбутніх лікарів. Розкрито особливості вивчення значущості мотивів формування предметних компетентностей студентів. Зазначено, що найбільшу цінність для студентів мають зовнішні мотиви, що відображають матеріальну зацікавленість особистості в результатах своєї професійної діяльності. В ієрархії мотивів студентів відповідно наступні рангові місця займають мотиви престижу, мотиви прояву особистості в професії та власне професійні мотиви. Мотиви власне професійної діяльності характеризують наявність у студентів інтересу до професії лікаря, прагненням до досягнення успіху в реалізації поставлених цілей. Доведено, що мотиви власне професійної діяльності складають ціннісну основу змісту професії.

Ключові слова: майбутні лікарі, студент, предметна компетентність, мотиви, ціннісно-мотиваційна сфера, діагностика, методика, опитування. 


\section{Література}

1. Бакуліна О. С. Сучасні проблеми мотивації персоналу сільськогосподарських підприємств. Роль науки у підвищенні технологічного рівня $і$ ефективності АПК України: матеріали 2-ї всеукр. наук.-практ. конф. з міжнар. Участю (м. Тернопіль, 16-18 травня 2012 р.). Тернопіль : Крок, 2012. С. 236-238.

2. Бакуліна О. С. Мотивація персоналу сільськогосподарських підприємств: теоретичний аспект. Вісн. наи. ун-ту водного господарства та природокористування. 2008. Вип. 4 (44). Ч. 5. С. 3-10.

3. Виленский М. Я. Технологии профессионально-ориентированного обучения в высшей школе: уч. пос. / под ред. В.А. Сластенина. Москва: Педагогическое общество России, 2002. 275 с.

4. Овсієнко Л. М. Проблеми впровадження компетентнісного підходу в процес підготовки майбутніх педагогічних кадрів. Украӥнська мова $і$ література в школі: науково-методичний журнал. Київ: Видавництво ТОВ «Лазурит-Поліграф», 2011. № 6. C. 46-48.

5. Петько С. М. Моделі корпоративного управління в діяльності корпорацій на світових ринках. Молодий вчений. 2015. №2 (17). Ч. 2. С. 225-229.

6. Петько Л. В. Виклики XXI століття для освітнього простору України. Наукові nраиі [Чорноморського державного університету імені Петра Могили комплексу "КиєвоМогилянська академія"]. Серія : Педагогіка : наук. журн. / Чорном. держ. ун-т імені Петра Могили; ред. кол. : О. П. Мещанінов (голова) [та ін.]. Миколаїв : Вид-во ЧНУ імені Петра Могили, 2017. Т. 303. Вип. 291. С. 10-14.

7. Петько Л В. Реалізація концепції підготовки магістрів в Україні для роботи в інклюзивному освітньому просторі // Актуальні проблеми навчання та виховання людей в інтегрованому освітньому середовищі: Тр. XI Міжнар. наук.-практ. конф., листопад 2011 р. Ч. І. Київ: ВМУРЛ «Україна». 2011. С. 92-94.

8. Тернопільська В. І. Відповідальність особистості: гуманітарний аспект. Вісник Житомир. держ. ун-ту ім. І. Франка. 2004. № 14. С 47-50.

9. Тернопільська В. І. Теоретичні засади реалізації ціннісного підходу у вихованні особистості. Нові технології навчання. 2016. Вип. 88. Ч. 2. С. 118-121.

10. Тернопільська В. І. Сучасні тенденції мотивації навчально-професійної діяльності студентів. Вісник Наџіонального університету оборони Украӥни, 2012. №5(30). C 141-144.

11. Тернопольская $\quad$ В. И., Бакулина $\quad$ О. С. Особенности формирования профессиональной компетентности будущих специалистов по налогообложению и таможенному делу. International scientific journal «Progress». Tbilisi : International Publishing House «Progress», 2018. № 1-2. P. 94-97.

12. Тернопільська В. І. Структура професійної компетентності майбутнього фахівця. Науковий вісник Мелітопольського державного педагогічного ун-ту. Серія: Педагогіка, 2012. № 9. С. 208-213. 
13. Тернопільська В. І., Чижова Н. В. Мобільність особистості як предмет наукового дослідження. Теоретико-методичні проблеми виховання дітей та учнівської молоді. 2016. Вип. 20. Кн. 2. С. 234-243.

14. Тернопільська В. І., Коломієць Т. В., Піонтківська І. О. Довідник з виховної роботи зі студентами: навч. посіб. Тернопіль : Вид-во «Богдан», 2014. $184 \mathrm{c}$.

15. Тернопільська В. І., Дерев'янко О. В. Визначення критеріїв сформованості професійної компетентності майбутніх гірничих інженерів. Наук. часопис НПУ імені М. П. Драгоманова. Пед. науки, 2012. Вип. 31. С. 264-267.

16. Babiy S., Bezkorovaina O., Matviienko O., Petko St., Ternopilska V., Soichuk R., Stanislavchuk N. Entrepreneurship model of professional development of actuaries in Canada // Journal of Entrepreneurship Education (JEI). USA. 2019. Vol: 22 Issue: 3. P. 1-6.

17. Ovsiienko Liudmyla. Innovative approaches to improving professional training of spesialists in higher educational institutions // Current scientific research: Collection of scientific articles. - Publishing house «BREEZE», Montreal, Canada, 2017. P. 215-220.

18. Ovsiienko L. M. Regularities of competently directed learning of text linguistics of studets' philological specialities // Economics, management, law: socio-economical aspects of development: Collection of scientific articles. Volum 2. Psychology. Pedagogy and Education. - Edizioni Magi - Roma, Italy. 2016. P. 245-250.

19. Pet'ko L. The development of student youth aesthetic culture on professional direction // Topical issues of contemporary science: Collection of scientific articles. - C.E.I.M., Valencia, Venezuela, 2017. P. 188-192. 